\title{
Virtual Reality Visualization of Tongkonan Traditional House as Promotional Media for Cultural Tourism using ADDIE Model
}

Cynthia Hayat ${ }^{*}$ David Panggeso

Department of Information System Krida Wacana Christian University West Jakarta

*Correspondence: cynthia.hayat@ukrida.ac.id

\begin{abstract}
Indonesia is a country that is rich in culture and customs. Indonesia also has great potential in the field of tourism, especially cultural tourism. The key to attracting tourist visitors lies in the information media provided. In this paper, a desktop-based application is developed with 3D virtual reality graphics model technology with Tongkonan traditional house from the Toraja tribe and their environment as the object. This $3 \mathrm{D}$ virtual reality visualization aims to be an interactive promotional media for the millennial generation in introducing cultural tourism, especially the Tongkonan traditional house of Toraja. In this application, the user can explore the traditional house objects as a whole - with the help of navigation control in the form of keyboard and mouse. The ADDIE model method was used in designing this desktop application. The user response test was used to measure respondents' attitudes toward the application using the Likert scale and succeeded in getting the very good category in 17 questionnaire statements and the good category in three questionnaire statements. Therefore, it can be concluded that the VR visualization of Tongkonan Traditional House can act as an interactive promotional media to the millennial generation.
\end{abstract}

Keywords: 3D virtual reality, traditional house, tongkonan, ADDIE model

Article info: submitted: June 5, 2020, revised: Aug 6, 2020, accepted: Sept 11, 2020

\section{Introduction}

Indonesia is a country that has a long history in terms of culture and customs. Some regions in Indonesia have collections of culture, art, and knowledge that become attractions for tourists. Data from the Central Statistics Agency (BPS) cited through the Indonesia Millennial Report in January 2019 described that dominating the demographic structure in Indonesia will be controlled by millennials with an age range of 18-30 years old. At present, the population in Indonesia is around 179.1 million people, $(67.6 \%)$ are of the productive age group, and $24 \%$ are of the millennial generation. The huge size of the target market of the millennial generation is the target market for the tourism industry. The millennial generation is known as an adventurous generation. From traveling, they get pleasure and experience. Not infrequently, millennial also makes traveling as a lifestyle choice.[1]

A preliminary survey conducted on the interest of attractive tourist destinations with millennial generation as the target respondent is shown in Figure 1 below.

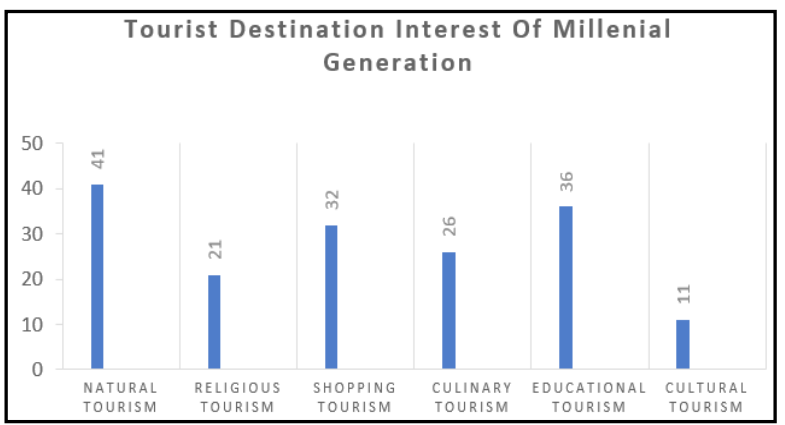

Figure 1. Tourist Destination Interest of Millenial Generation

From the preliminary survey results, it is concluded that the interest of millennial generation towards cultural tourism is currently the lowest at $11 \%$ compared to natural tourism by $41 \%$, religious tourism $21 \%$, shopping tourism $32 \%$, culinary tourism $26 \%$ and educational tourism as much as $36 \%$.

Cultural tourism puts forward the types of tourism activities that use culture as an object. One of the cultural elements contained in cultural tourism is the form and 
architecture where in this case is the architecture of a house or a traditional house. According to Faisal, R.M, (2014) in his research, he explained that traditional house is a house that characterizes a certain region that symbolizes the culture of the local community. Until now, many tribes in Indonesia still maintain their traditional houses as an effort to preserve the values of their culture.

Tongkonan traditional house is a traditional house from the Toraja region located in South Sulawesi Province, Indonesia. Various potentials---ranging from beautiful tourist attractions, preserved local wisdom, and the form of traditional house---that are considered unique, makes Toraja a regency that is quite prominent in tourism surveyed according to the official tourism website.

The diversity of Indonesian culture has not been utilized by the government as cultural tourism attractions. According to an article reported by Arthur in his interview with Yohan Tangkesalu as the Tourism Promotion Agency for the 20182021 period, he was stated that the number of tourist attractions was still lacking, so that efforts are needed to advance tourism in the Toraja region in terms of promotion, especially the Tongkonan traditional house. To make the tourism sector of an area develops, it must be supported by good and attractive tourism promotion. Also, according to Apriani \& Pahrul Irfan, tourism promotion can be done digitally or conventionally.[2] According to Martin Lister et al. The delivery of information through conventional media such as brochures, flyers, banners, and other print media is currently inadequate to attract. This is because objects such as parks, environments, and buildings are 3-dimensional objects. The project is not yet completed if the objects are only shown in 2-dimensional. The preliminary survey stated that the current millennial generation is more interested in getting information from digital/online media (about 57\%) compared to getting information from friends/relations (about 22\%) and from print/conventional media (about $21 \%)$.

Therefore, an approach needs to be conducted by making prospective tourists be able to observe or learn visually regarding the shape of the tourist attraction design before actually visiting it directly. According to Novrisa W. Wulandari in her writing, it states that, in average, a human is only able to remember $20 \%$ of the information heard, while $30 \%$ remember the information seen, and almost $90 \%$ of people can remember information based on what is experienced.[3] The design of promotional media for Tongkonan traditional house that will be offered used 3D Virtual Reality or 3-dimensional virtual reality that is used to observe things in a whole in the virtual world - simulated by a computer. Therefore, when people watch the virtual world, this is as if people experience first hand the incident. Ikpe Justice and Murali Shanker concluded that the visualization of the $3 \mathrm{D} / \mathrm{VR}$ model is more effective compared to the visualization of the 2-D model.[4]

Virtual Reality (VR) is a technology that enables users to interact with certain environments that are imitated, including the shape and appearance of the environments simulated by a computer, which is known as computer- simulated environment. By implementing VR, users can interact with virtual environments using standard input such as keyboard and mouse. At present, visual experiences are in the form of virtual reality. The visual experiences are generally displayed on a computer screen and sometimes displayed through stereoscopic VR. Some visualizations also contain information from sensing result including sound through the speaker[5][6].

According to Lacrama, the concept of VR refers to the system principles, techniques and, methods used in designing software products. The concept of VR is then used with the assistance of multimedia computer systems with specific device systems[7][8].

Judging from its ability, VR technology has the potential as a medium for cultural tourism promotion[9]. Users can directly interact with artificial objects and their environment. Users can also get a sensation from their sense of hearing. The advantages of VR include the ability in offering experiences resembling the real world. Hence in this paper, a DesktopBased 3D Virtual Reality Visualization of Tongkonan Traditional House was developed. This application becomes an interactive promotional media to introduce Indonesian cultural tourism, especially traditional house tourism to the millennials. This promotional media product can be distributed to an event held by Tourism Promotion Board i.e. in exhibitions of traditional houses targeting the millennial generation.

\section{Methods}

\section{a. Data Collection}

Data sources are divided into two types, namely primary data and secondary data. Primary data is data obtained directly through the results of questionnaires that have been distributed randomly. The results were in the form of (1) data frequency report containing diagrams for the distribution of the first questionnaire, and (2) data frequency report containing percentages for the distribution of the second questionnaire. Secondary data was obtained indirectly through the collection of journals, thesis guidelines, books, and several articles on the internet.

The data collection instrument used in this study was questionnaires. This instrument is used to assess the effectiveness of the making of a research application. Data obtained from this questionnaire was quantitative data. The questionnaire is an efficient data collection technique (Sugiono 2013). The results of this questionnaire were quantified and analyzed to draw conclusions. Questionnaires were distributed twice, namely:

\section{b. First Questionnaire Instrument}

The making of the first questionnaire instrument was aimed at millennials from the age range of 18-30 years old. The first questionnaire was created using the google form questionnaire in order to obtain preliminary data - which is used to support the research problem. The questionnaire consisted of 8 questions reviewed in 3 aspects namely age, tourist destination, and promotional media. 
Table 1. First Questionnaire Instrument

\begin{tabular}{cllcc}
\hline No & \multicolumn{1}{c}{$\begin{array}{c}\text { Assessment } \\
\text { Aspects }\end{array}$} & \multicolumn{1}{c}{ Indicators } & $\begin{array}{c}\text { Number } \\
\text { of Items }\end{array}$ & $\begin{array}{c}\text { Question } \\
\text { Number }\end{array}$ \\
\hline 1 & Age & $18-30$ years old & 1 & 1 \\
2 & Tourist Destination & Interest to tourist destination & 2 & 2,4 \\
& & Frequency of visits & 1 & 3 \\
3 & \multirow{2}{*}{ Promotional Media } & Interest to promotional media & 2 & 5,8 \\
& & Influence of promotional media & 2 & 6,7 \\
\hline
\end{tabular}

Table 2. Summary of User Response Instrument

\begin{tabular}{cllcc}
\hline No & $\begin{array}{c}\text { Assessment } \\
\text { Aspects }\end{array}$ & \multicolumn{1}{c}{ Indicators } & $\begin{array}{c}\text { Number } \\
\text { of Items }\end{array}$ & Question Number \\
\hline 1 & Display & 3D Graphic & 6 & $1,2,3,4,5,6$ \\
& & Musical Instrument & 2 & 7,8 \\
2 & Information & Information contents and language usage & 7 & $9,10,11,12,13,14,15$ \\
3 & Usability & Clarity of use & 3 & $16,17,18$ \\
4 & Reliability & Navigation Performance & 2 & 19,20 \\
\hline
\end{tabular}

\section{c. Second Questionnaire Instrument}

The making of the user response instrument was addressed to millennials with an age range of 18-30 years old. The data was obtained randomly through questionnaire distribution. The results of this questionnaire were used as a measurement tool for testing the feasibility of the application for the millennial generation. Table 2 is the summary of the user response instrument.

Based on table 2, the evaluation aspects are the core questions of the questionnaire which consists of 4 aspects: display, information, usability, and reliability. Indicators are the subset of the core questions. This user response questionnaire consists of 20 questions to find out the percentage of the feasibility of the application developed.

\section{d. Research Steps}

The steps of research in developing Tongkonan Traditional House VR are explained as follows:

Data :Data collection used to develop Collection virtualization of Tongkonan Traditional House 3D VR.

Requirement : Formulation of the problem and Analysis recommendations given to solve the problem by using information technology.

Initial 3D :Designing the shape of the traditional Model house as a whole using the blender 2.79b Development software as well as the objects contained, in the form of 3-dimensional graphics.

Scientific : Creating a model design using the unity Development 3D 5.6.7fl software by converting the 3-dimensional graphical models that have been created into $3 \mathrm{D}$ virtual reality form that can be accessed through the control application. Furthermore, adding information on each object contained in the traditional house and other displays by embedding navigation controls using keyboard and mouse inputs.

Testing : Testing was done to assess the feasibility of the application being developed. The user response test was then analyzed and concluded from each question whether the user's response is in line with the desired results or not.

Final Model : The final model was generated after testing the user's response to the application developed.

\section{e. ADDIE Model}

The development of learning model used in this study is the ADDIE (Analysis-Design-DevelopImplement-Evaluate) Learning Design Model. This model is combined according to the research and development steps recommended by Borg and Gall based on several considerations such as suitable for developing instructional model product/targeted; effective and dynamic learning; and very helpful in the development of learning for teachers. The ADDIE instructional design model developed by Reiser and Mollenda (1990s) is a generic learning/training design model that guides the establishment of training tools and infrastructure - that are effective, dynamic and support training performance itself. Thus helping training instructors in managing training and learning [10][11].

Research and development methods are used to produce a particular product and to test the product itself. The test benefits to measure the effectiveness of a product. ADDIE model consists of five stages, including analysis, design, development, implementation, and evaluation [12]. 


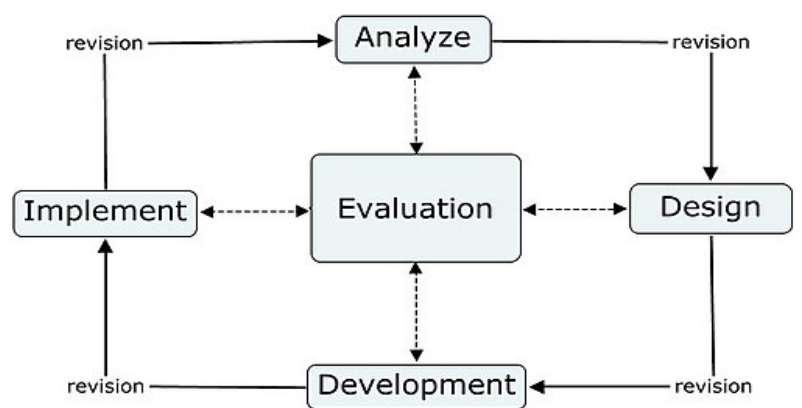

Figure 2. ADDIE Model

Source: Forest, E. (2014)

Figure 2 illustrates the five components of the ADDIE Model that are interrelated in a structured and systematic way, in which the first stage to the last stage in its distribution must be systematic and cannot be randomized in order.

Stage 1 : Analysis. The analysis phase is a process of requirements assessment (requirements analysis), identifying problems, and conducting task analysis. The outputs generated were the characteristics or profile of prospective students, the identification of requirements and detailed task analysis based on the requirements.

Stage 2 : Design. This stage is known as blueprint making. Like constructing a building, before being built, there must be a design on paper.

Stage 3 : Development. It is the process of realizing the blueprint or the design into reality. This means that at this stage, everything that is needed or that will support the learning process must all be prepared.

Stage 4 : Implementation. This step is a concrete step to implement the learning system that has been made. That means, in this stage, every element that has been developed is installed or set in such a way according to its role or function so that it can be implemented. After the product is ready, it is tested to a large group. Then it is evaluated and revised. After that, trials can be carried out on large groups and then re-evaluated and revised to produce a final product that is ready to be deployed.

Stage 5: Evaluation. Evaluation is the process of observing whether the learning system being built is successful according to initial expectations or not. The evaluation phase was carried out at each of the four stages above. This evaluation method is called formative evaluations. The reason for choosing this method is for the purpose is for the revision needs. For example, at the design stage, we need expert review to provide input to the design we are making.

\section{Results}

\section{a. 3D Blueprint of Tongkonan Traditional House}

At the design stage, also known as blueprint making, before the construction starts, there must be a design on paper. The following figures are the blueprint designs for some of the tongkonan traditional house display designs. [13][14]

1) Design of the Front View of the Traditional House
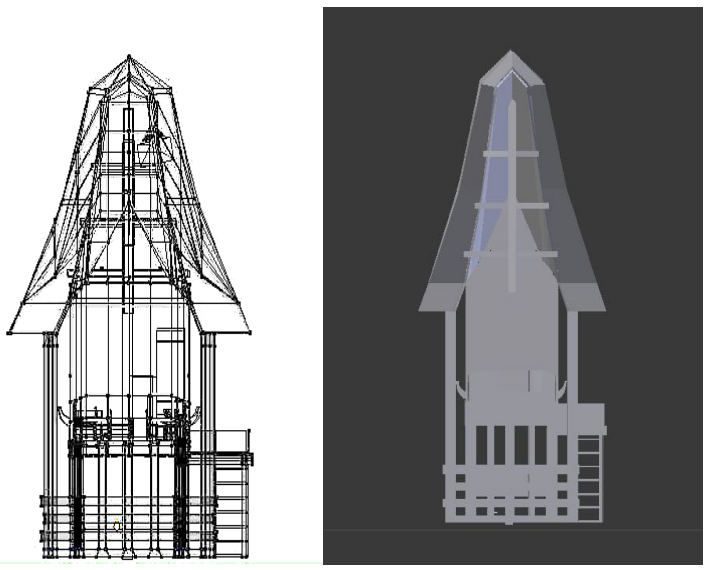

Figure 3. Blueprint of the Front View of the Traditional House

Figure 3 is the design of the front view of the Tongkonan traditional house. The left subfigure is the shape of the house in Blueprint view while the right subfigure is the shape of the house in solid form.

2) Design of the Right Side View of the Traditional House

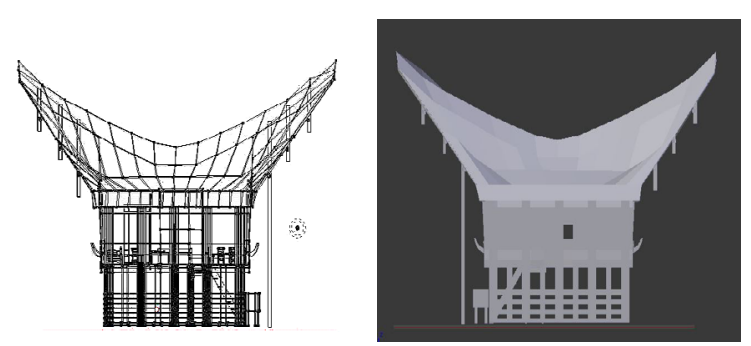

Figure 4. Blueprint of the Right Side of the Traditional

House

Figure 4 is the view from the right side of the Tongkonan. The left subfigure is the shape of the house in Blueprint view while the right subfigure is the picture is the shape of the house in solid form.

3) Design of Interior Layout Display of the Traditional House

Figure 5 is the design of interior layout display of Tongkonan traditional house when being viewed from the $\mathrm{Z}$-axis (top view). The left subfigure is the shape of the house in Blueprint view while the right subfigure is the shape of the house in solid 
form. These layouts are the layout of the middle part of the traditional house (Kale Banua) where there are three rooms in it. The first room on the right is called Tangdo, the second room in the middle is called Sali, and the third room on the left is called Sumbung.
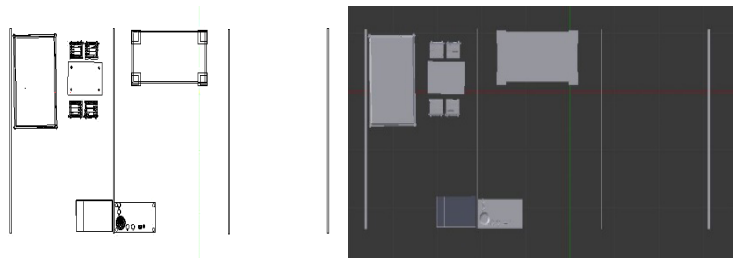

Figure 5. Blueprint of the Right Side of the Traditional House

\section{b. Development of Tongkonan Traditional House}

This step was carried out after the design making. The following are the results of the development step that have been made [2][8][15][16].

1) Front and Rear Views of the Traditional House Figure 6 depicts the views from the front and rear sides of the Tongkonan traditional house that have been made:

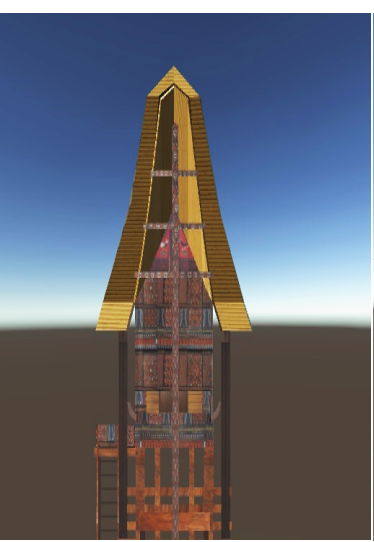

Front View

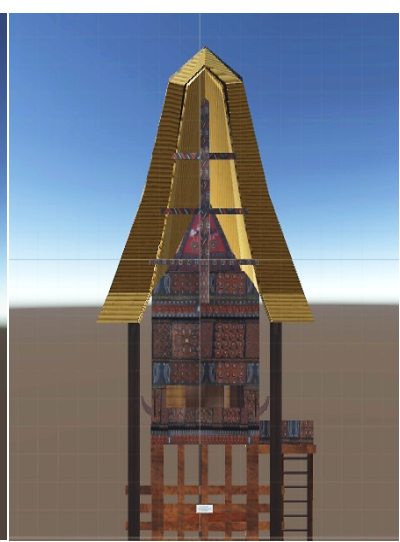

Rear View
Figure 6. Front and Rear Views of the Traditional House

Figure 6 is the result of the previous design, in which there are additional materials such as wood, bamboo and boards, as well as textures on each layer of the traditional house in the form of wood textures and Toraja batik carving models.

2) The Display of the Left and Right Sides of the Traditional House

The following are the displays of the left and right sides of Tongkonan traditional house that have been made:

Figure 7 is the result of the previous design, in which there are additional materials such as wood, bamboo and boards, as well as textures on each layer of the traditional house in the form of wood textures and Toraja batik carving models.

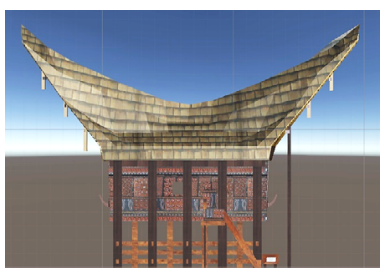

Left Side

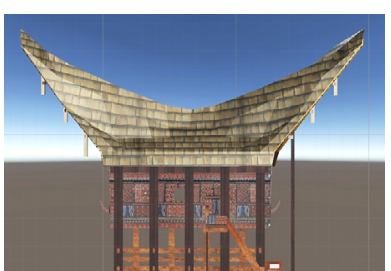

Right Side
Figure 7. Left and Right Side Views of the Traditional House

3) The Display of the Rooms in the Traditional House The following figures are the displays of the rooms in the Tongkonan traditional house that have been made:
First Room

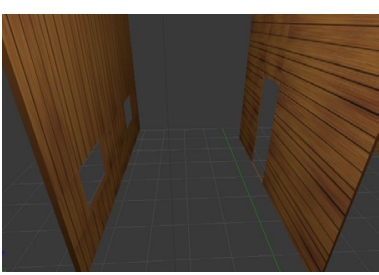

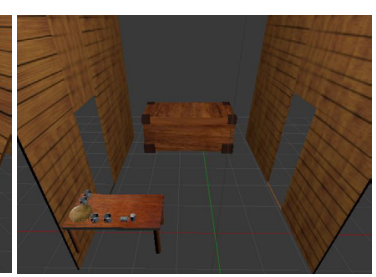

Second Room
Figure 8. The Display of First and Second Rooms of the Traditional House

Figure 8 is the result of the previous design, in which there are additional materials such as wooden walls, wallboard, and wood texture on each layer of the room for the first room. The second room is the result of the previous design, in which there are additional materials such as a wooden coffin, wooden board, glass cups, plates and tables and wood textures, plates and cups at each layer of the room.

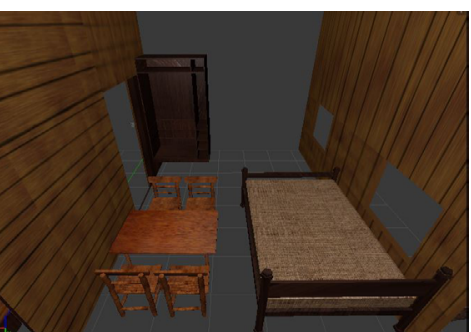

Figure 9. The Display of The Third Room (Sumbung)

Figure 9 is the result of the previous design, in which there are additional materials such as wooden walls, chairs, tables, mattresses, cabinets, as well as fabric textures for mattresses, wooden cabinet, wooden table, and chairs on each layer of the room.

\section{c. Implementation of Tongkonan Traditional House 3D VR}

This stage is the stage after the development of the traditional house, namely the design and development. 
This phase is presented in the form of a desktop application.

1) Main Menu

The following is the display of the main menu when the application is opened:

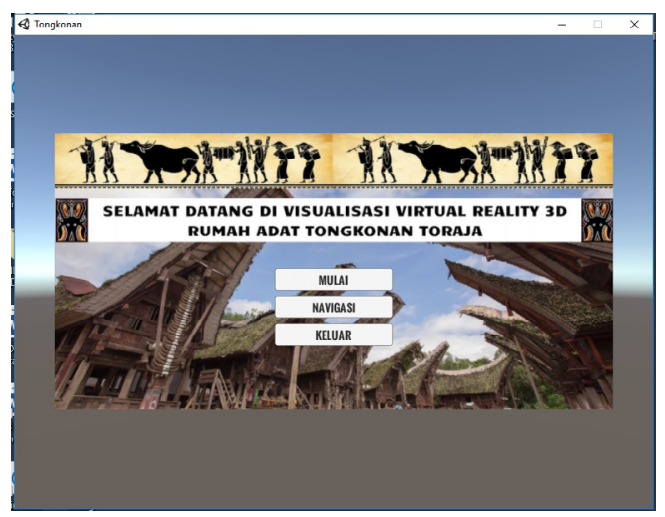

Figure 10. The Display of Main Menu

Figure 10 is the initial appearance when the application is opened. There are greetings and three menus that can be selected by the user, e.g. start menu, navigation menu, and exit menu.

2. Navigation Control

The following figure is the display of navigation control contained in the navigation menu on the main menu:

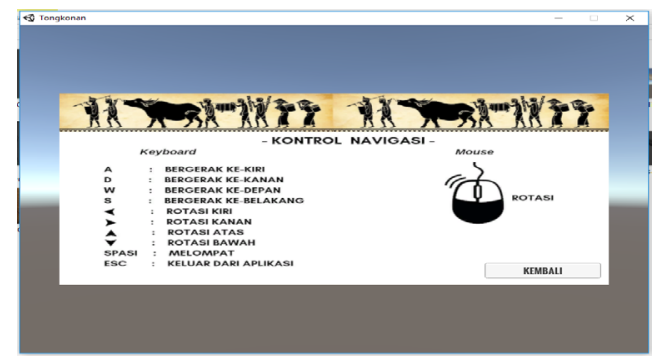

Figure 11. The Display of Navigation Control

Figure 11 is the display of the navigation menu on the main menu. It serves a user guide run the application. There are guidelines for using the keyboard and mouse.

3. The Display of The Information

The following figures are the displays when the user arrives at several objects.

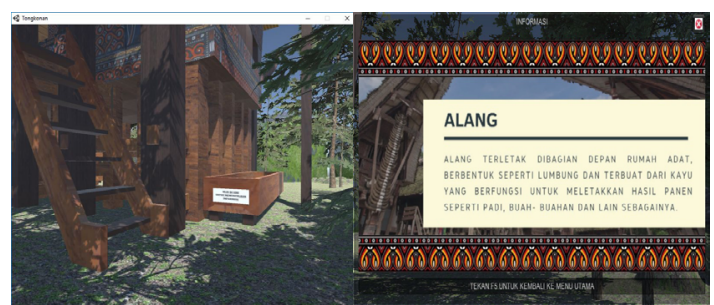

Figure 12. The Display of Alang Object
Figure 12 is a display of Alang located in front of the traditional house. There is an information to be clicked the Alang object on the side. There is the title of the object then followed by a brief description of the object.

The following figures are the display when the user arrives at the Sulluk section:
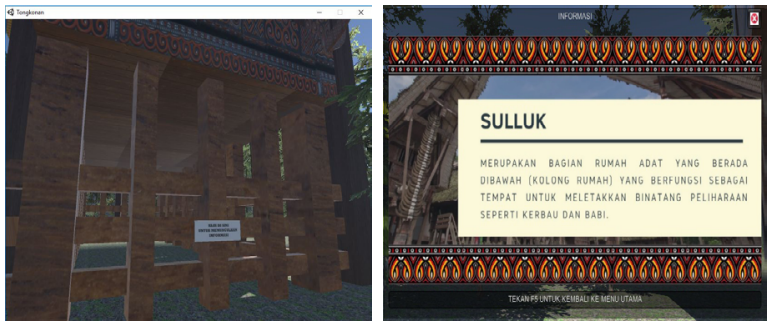

Figure 13. The Display of Sulluk Section

Figure 13 is a display of Sulluk section which is located behind the traditional house. There is an information to be clicked on the Sulluk section which is situated on the Sulluk pole.

The following is the display when the user arrives at the Inan Pa Bulan object:
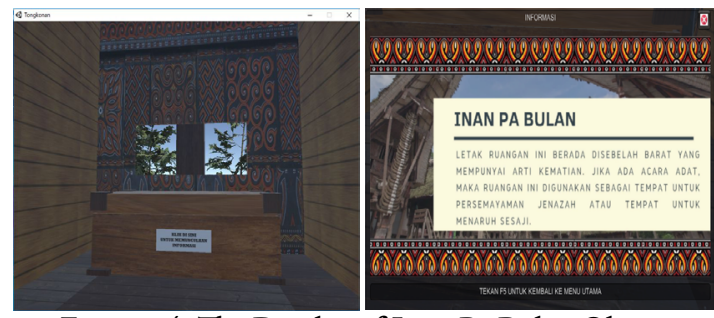

Figure 14. The Display of Inan Pa Bulan Object

Figure 14 is a display of Inan Pa Bulan object found in the second room of the traditional house. There is an information to be clicked on the front side of the chest. There is the title of the object then followed by a brief description of the object.

The following is the display when the user arrives at the Pa Dukkuan Api object:

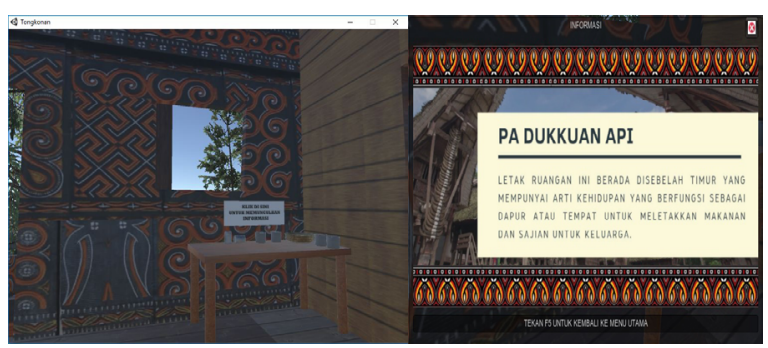

Figure 15 The Display of Pa Dukkuan Api Object

Figure 15 is a display of Pa Dukkuan Api object in the second room of the traditional house. There is an information to be clicked on the top of Padukkuan Api object. 
The following figures are the display when the user arrives at the Tangdo section:
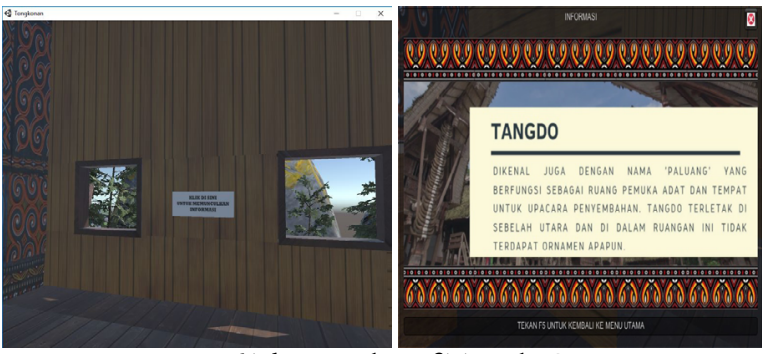

Figure 16 The Display of Tangdo Section

Figure 16 is a display of the Tangdo section in the first room of the traditional house. There is information to be clicked on the wall of the room.

The following figures are the display when the user arrives at the Sumbung section:
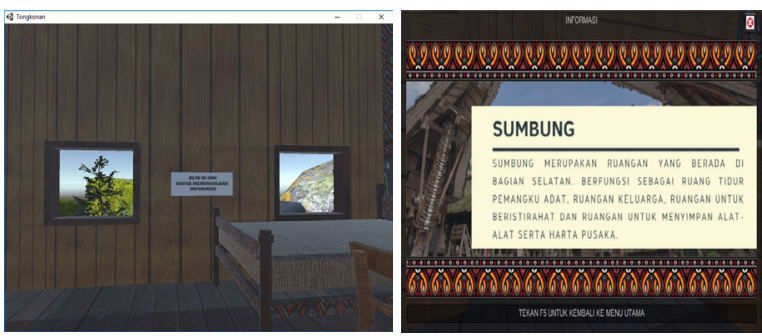

Figure 17 The Display of Sumbung Section

Figure 17 is a display of the Sumbung section in the third room of the traditional house. There is information to be clicked on the wall of the room.

\section{d. User Response Evaluation}

The evaluation of this study is in the form of a user response test, conducted by distributing questionnaires to 50 respondents who knew about the Tongkonan traditional house or the culture of the Toraja tribe. Questionnaires were given to be answered by respondents by giving 20 statements about the application which were equipped with information. The statements were measured with a range from very good (VG) to very poor (VP). Then to calculate the results of the quantity, Likert scale calculation was used.

Table 3 is the result of calculating the number of scale values and frequency of each statement. The is information in the form of a scale category at each frequency statement as well as the percentage of answers for each statement.

Table 3. Final Results of User Response Test

\begin{tabular}{|c|c|c|c|c|c|c|c|c|}
\hline \multirow[b]{2}{*}{$\begin{array}{l}\text { Question } \\
\text { Number }\end{array}$} & \multicolumn{5}{|c|}{ Scale } & \multirow[b]{2}{*}{ Frequency } & \multirow[b]{2}{*}{ Category } & \multirow[b]{2}{*}{ Percentage } \\
\hline & $\begin{array}{l}\text { VG } \\
(5)\end{array}$ & $\begin{array}{c}\text { G } \\
(4) \\
\end{array}$ & $\begin{array}{l}\text { CB } \\
\text { (3) }\end{array}$ & $\begin{array}{c}\mathbf{P} \\
(2) \\
\end{array}$ & $\begin{array}{l}\text { VP } \\
(1)\end{array}$ & & & \\
\hline 1 & 100 & 76 & 33 & 0 & 0 & 209 & SB & $84 \%$ \\
\hline 2 & 75 & 100 & 27 & 2 & 0 & 204 & SB & $82 \%$ \\
\hline 3 & 85 & 108 & 18 & 0 & 0 & 211 & SB & $84 \%$ \\
\hline 4 & 85 & 80 & 18 & 14 & 0 & 197 & B & $99 \%$ \\
\hline 5 & 115 & 92 & 12 & 0 & 0 & 219 & SB & $88 \%$ \\
\hline 6 & 130 & 80 & 12 & 0 & 0 & 222 & SB & $89 \%$ \\
\hline
\end{tabular}

\begin{tabular}{|c|c|c|c|c|c|c|c|c|}
\hline \multirow{2}{*}{$\begin{array}{l}\text { Question } \\
\text { Number }\end{array}$} & \multicolumn{5}{|c|}{ Scale } & \multirow[b]{2}{*}{ Frequency } & \multirow[b]{2}{*}{ Category } & \multirow[b]{2}{*}{ Percentag } \\
\hline & $\begin{array}{l}\text { VG } \\
(5) \\
\end{array}$ & $\begin{array}{c}G \\
(4)\end{array}$ & $\begin{array}{l}\text { CB } \\
\text { (3) } \\
\end{array}$ & $\begin{array}{c}\mathbf{P} \\
(2)\end{array}$ & $\begin{array}{l}\text { VP } \\
(1) \\
\end{array}$ & & & \\
\hline 7 & 185 & 44 & 3 & 0 & 0 & 232 & SB & $93 \%$ \\
\hline 8 & 175 & 60 & 0 & 0 & 0 & 235 & SB & $94 \%$ \\
\hline 9 & 95 & 108 & 12 & 0 & 0 & 215 & SB & $86 \%$ \\
\hline 10 & 125 & 68 & 15 & 0 & 0 & 208 & SB & $86 \%$ \\
\hline 11 & 125 & 68 & 9 & 0 & 0 & 202 & SB & $85 \%$ \\
\hline 12 & 40 & 100 & 48 & 0 & 0 & 188 & B & $95 \%$ \\
\hline 13 & 90 & 108 & 15 & 0 & 0 & 213 & SB & $85 \%$ \\
\hline 14 & 95 & 104 & 15 & 0 & 0 & 214 & SB & $86 \%$ \\
\hline 15 & 115 & 92 & 12 & 0 & 0 & 219 & SB & $88 \%$ \\
\hline 16 & 95 & 108 & 12 & 0 & 0 & 215 & SB & $86 \%$ \\
\hline 17 & 130 & 96 & 0 & 0 & 0 & 226 & SB & $90 \%$ \\
\hline 18 & 80 & 104 & 24 & 0 & 0 & 208 & SB & $83 \%$ \\
\hline 19 & 95 & 112 & 9 & 0 & 0 & 216 & SB & $86 \%$ \\
\hline 20 & 60 & 80 & 39 & 10 & 0 & 189 & B & $95 \%$ \\
\hline
\end{tabular}

\section{Conclusion}

Based on the results of the analysis and discussion that have been carried out, as well as testing of some user responses, the following conclusions are obtained:

1. The results of this application development allow users to explore the entire area of the Tongkonan Traditional House which is controlled by the user using keyboard and mouse inputs. The feature contained in the application is user interaction with objects that can display information of the object selected by the user. This application is also equipped with a musical instrument to support the atmosphere.

2. The results of the user response test to 50 respondents concerning to the $3 \mathrm{D}$ virtual reality visualization of desktop-based Tongkonan traditional house are 17 statements with 4 indicators. The given applications were answered 'Very Good' by 50 respondents as many as three statements were answered 'Good' by 50 respondents. Therefore, it can be concluded that this visualization can act as an interactive promotional media to the millennial generation.

For the research development, the concept of Virtual Reality can be developed in the form of Virtual Reality Simulation by creating an interesting and effective learning experience. Also, the Virtual Reality can be developed with interactive technology from real-world objects where objects from the virtual world seem to appear from real objects in 3D. Hence, users can get a more interactive user experience like the real world.

\section{References}

[1] P. Irfan and A. Apriani, "Analisa Strategi Pengembangan E-Tourism Sebagai Promosi Pariwisata di Pulau Lombok," Ilk. J. Ilm., vol. 9, no. 3, 2017, doi: 10.33096/ilkom.v9i3.164.325330 . 
[2] A. Pramono, "Media Pendukung Pembelajaran Rumah Adat Indonesia Menggunakan Augmented Reality," J. ELTEK, vol. 11, no. 1, 2013.

[3] Widada and Rosyidi, "Perancangan Media Pembelajaran Fisika SMP Berbasis Multimedia Interaktif," J. IT CIDA Vol. 3 No. 2 Desember 2017, vol. 3, no. 2, 2017.

[4] I. J. Akpan and M. Shanker, "A comparative evaluation of the effectiveness of virtual reality, 3D visualization and $2 \mathrm{D}$ visual interactive simulation: an exploratory meta-analysis," Simulation, vol. 95, no. 2, 2019, doi: 10.1177/0037549718757039.

[5] D. W. F. Van Krevelen and R. Poelman, "A Survey of Augmented Reality Technologies, Applications and Limitations," Int. J. Virtual Real., vol. 9, no. 2, 2010, doi: 10.20870/ijvr.2010.9.2.2767.

[6] T. Sunarni and D. Budiarto, "Persepsi Efektivitas Pengajaran Bermedia Virtual Reality (VR)," Semin. Nas. Teknol. Inf. Komun. Terap. 2014, vol. 4, no. 1, 2014 .

[7] K. Laver, S. George, S. Thomas, J. E. Deutsch, and M. Crotty, "Virtual reality for stroke rehabilitation," Stroke. 2012, doi: 10.1161/ STROKEAHA.111.642439.

[8] B. Sihite, Samopa, and N. A. Sani, "Pembuatan Aplikasi 3D Viewer Mobile dengan Menggunakan Teknologi Virtual Reality,” Tek. POMITS, vol. 2, no. 2, 2013.

[9] D. A. Guttentag, "Virtual reality: Applications and implications for tourism," Tour. Manag., vol. 31, no. 5, 2010, doi: 10.1016/j.tourman.2009.07.003.

[10] I. M. Tegeh and I. M. Kirna, "Pengembangan Bahan Ajar Metode Penelitian Pendidikan Dengan Addie Model,” J. Ika, vol. 11, no. 1, 2013.

[11] B. M. Ngussa, "Application of ADDIE Model of Instruction in Teaching-Learning Transaction among Teachers of Mara Conference Adventist Secondary Schools, Tanzania,” J. Educ. Pract., vol. 5, no. 25, 2014.

[12] R. S. Nadiyah and S. Faaizah, "The Development of Online Project Based Collaborative Learning Using ADDIE Model," Procedia - Soc. Behav. Sci., vol. 195, pp. 1803-1812, 2015, doi: 10.1016/j. sbspro.2015.06.392.

[13] S. Sukirman, W. A. Reza, and S. Sujalwo, "Media Interaktif Berbasis Virtual Reality untuk Simulasi Bencana Alam Gempa Bumi dalam Lingkungan Maya," Khazanah Inform. J. Ilmu Komput. dan Inform., vol. 5, no. 1, 2019, doi: 10.23917/khif. v5i1.8054.

[14] L. Hakim, "Pengembangan Media Pembelajaran Pai Berbasis Augmented Reality," Lentera Pendidik. J. Ilmu Tarb. dan Kegur., vol. 21, no. 1, 2018, doi: 10.24252/lp.2018v21n1i6.
[15] A. Suhendar and A. Fernando, "Aplikasi Virtual tour Berbasis Multimedia Interaktif Menggunakan Autodesk 3Ds Max," ProTekInfo, vol. 3, no. 1, 2016.

[16] F. S. Riyadi, A. Sumarudin, and M. S. Bunga, "Aplikasi 3d Virtual Reality Sebagai Media Pengenalan Kampus Politeknik Negeri Indramayu Berbasis Mobile," Jiko (Jurnal Inform. dan Komputer), vol. 2, no. 2, 2017, doi: 10.26798/ jiko.2017.v2i2.76. 